\title{
Netralitas Birokrasi Dalam Pemilihan Kepala Daerah Di Kabupaten Belu Periode 2020-2025
}

\author{
${ }^{1}$ Donatus Sae, ${ }^{2}$ Dedi Supriadi \\ ${ }^{1}$ Ilmu Pemerintahan STISIP Fajar Timur Atambua \\ ${ }^{2}$ Ilmu Pemerintahan Institut Ilmu Sosial dan Ilmu Budaya Samawa Rea \\ Email: donatussae1234@gmail.com ${ }^{1}$ dediadventure1@gmail.com²
}

\begin{abstract}
Abstrak. Netralitas birokrasi merupakan pertanyaan berputar dan berulang dalam setiap moment pemilihan umum baik tingkat lokal maupun tingkat nasional. Pertanyaan tersebut lahir dari siksp skeptic yang sangat dalam dan sulit diurai. Hal ini terjadi karena birokrat berada pada dua sisi yakni sebagai aparatur pemerintah dan sebagai pelayan masyarakat. Sebagai aparatur milik pemerintah birokrat berada di bawah kendali pemerintah dalam hal ini kepala eksekutif karena jabatan yang diperoleh birokrat merupakan pemberian kepala eksekutif. Dalam situasi tertentu birokrat berada di bawah kendali pemerintah dalam hal ini kepala eksekutif. Di sisi lain kehadiran birokrat sebagai pelayan rakyat mengharuskan birokrat bertanggungjawab untuk menghadirkan pelayanan kepada masyarakat secara profesional. Dua sisi tersebut mrmiliki tujuan yang sama yakni menghadirkan pelayanan prima, tetapi kadangkala berbenturan dalam sikap yakni antara berpihak kepada tuan (kepala eksekutif) atau kepada masyarakat sebagai subyek layanan. Benturan tersebut mengakibatkan birokrat berada dipersimpangan dilematis, antara memihak kepada kepentingan eksekutif sebagai pemberi jabatan atau berpihak kepada pelayanan yang professional berdasarkan sumpah jabatan. Hal inilah menyebabkan birokrasi cenderung tidak bersikap netral. Realitas menunjukkan bahwa birokrat cenderung berpihak kepada kepala eksekutif. Apabila sudah berada pada situasi demikian maka rakyat diabaikan. Tindakan ini secara tidak sadar mengangkangi demokrasi yang mana menempatkan rakyat sebagai pemilik kedaulatan tertinggi, dan sebagai alasan lahirnya birokrasi.
\end{abstract}

Kata kunci; Netralitas Birokrasi, Pelayan Public

\section{PENDAHULUAN}

Pemilihan kepala daerah Kabupaten Belu periode 2020-2025 merupakan ajang demokrasi rakyat dalam mencari dan menemukan pemimpin tingkat daerah Kabupaten Belu. Ajang tersebut merupakan pesta seluruh masyarakat Kabupaten Belu termasuk juga kaum birokrat. Birokrat yang dimaksud adalah mereka yang bekerja pada kantor-kantor pemerintahan baik sebagai PNS (Pegawai Negeri Sipil) maupun sebagai tenaga kontrak daerah.

Birokrat sebagai abdi negara dan pelayan masyarakat pada tingkat daerah Kabupaten Belu dan sebagai bagian dari masyarakat tidak dapat mengelak dari pengaruh dan gesekan pemilihan kepala daerah kabupaten. Birokrat dituntut untuk meneggakan panggilan nuraninya sebagai abdi negara, aparatur pemerintah, pelayan rakyat yang yang harus bersikap netral dalam hal ini tidak boleh memihak salah satu pasangan calon. Tetapi sebagai subyek yang memilik kecenderungan dan hak pilih, birokrat cenderung untuk condong pada pasangan calon yang diinginkan suara hatinya.

Pada titik ini birokrat berada pada ruang dilematis, berpihak pada rakyat susuai tuntutan demokrasi atau berpihak kepada eksekutif sebagai pemilik birokrasi.

Situasi ini sering mencuat ke permukaan dan mengundang tanya dari masyarakat luas, sanggupkah birokrasi bersikap netral dalam pemilihan kepala daerah? Sanggupkah birokrat memberikan pelayanan yang professional sesuai tuntutan profesinya ataukah birokrat 
cenderung berpihak kepada eksekutif sebagai pengendali birokrat?

\section{METODOLOGI PENELITIAN}

Penelitian ini mengulas netralitas birokrasi Kabupaten Belu dalam pemilihan kepala daerah Kabupaten Belu periode 20202025. Penelitian ini menggunakan pendekatan deskriptif kulitatif sebagai metode analisis data. Sampel penelitian adalah birokrat dalam hal ini ASN Kabupaten Belu. Pengumpulan data berdasarkan situasi riil ASN Kabupaten Belu. Sesudah itu peneliti menggambarkan hasil observasi berdasarkan kondisi riil di lapangan

\section{HASIL DAN PEMBAHASAN}

Pemilihan kepala daerah Kabupaten Belu periode 2020-2025 diikuti oleh dua pasangan calon yakni pasangan calon yakni pasangan calon Wilibrodus Lay-Drs J.T Ose Luan (SAHABAT) dan pasangan calon dr.Agustinus Taolin, Sp. PD-KGEH bersama Aloysius Haleserens, MM (SEHATI). Perhelatan ini melibatkan seluruh komponen dalan sistem politik. Gabriel Almond membagi sistem politik dalam enam bagian yakni kelompok kepentingan, partai politik, badan legislative, badan eksekutif, birokrasi dan badan peradilan. Dalam perspektif demokrasi yang menempatkan masyarakat sebagai pemegang kedaulatan tertinggi, demokrasi electoral tingkat Kabupaten Belu mendorong partisipasi seluruh masyarakat demokrasi secara menyeluruh dan secara khusus masyarakat Kabupaten Belu yang memiliki hak pilih termasuk masyarakat birokrasi.

Birokrasi dalam tulisan ini merujuk pada (Ramlan Surbakti) biro (bureau) yang berarti kantor atau dinas dan kata krasi (kratie) yang berarti pemerintahan. Dengan demikian birokrasi dapat diartikan sebagai dinas pemerintahan. Birokrasi sebagai salah satu unsur dari masyarakat Kabupaten Belu yang memiliki hak pilih ikut berpartisipasi dalam demokrasi lima tahunan. Partisipasi birokrasi dalam pesta demokrasi mengundang tanya, sanggupkah birokrat bersikap netral? Keterlibatan ini mengusik status quo birokrasi dalam karangka pikir Max Webber sebagai organisasi pemerintahan yang harus bersikap netral dalam politik praktis. Pendapat ini berbeda dengan rumusan birokrasi sebagai suatu organisasi pemerintahan yang dapat berkembang menjadi penguasa, birokratik polity atau birokratis otoriter (Ramlan;2007 hal. 185)

Sikap skeptic terhadap netralitas birokrasi dalam demokrasi electoral Kabupaten Belu tanggal 9 Desember 2020 bukan tanpa alasan. Rasa skeptic tersebut berangkat dari fakta sejarah birokrasi bangsa Indonesia. Pada era kepemimpinan Soeharto selama kurun waktu 32 tahun birokrasi Indonesia dijadikan alat pemenangan calon dari partai GOLKAR (Agus Dwiyanto; 2008 hal.31). Pengalaman ini mengendap dan sering muncul kembali ke permukaan pada saat pemilihan umum.

Berkaca pada pengalaman tersebut di atas birokrasi berjuang mereformasi dirinya. Lahirlah berbagai aturan yang bersifat mengikat ASN, sehingga partisipasi ASN dalam pemilihan umum pada tingkat lokal dan nasional berdasarkan pada asas dan aturan yang berlaku. Tujuannya adalah birokrasi bersikap netral dalam hal ini tidak menjadi alat politik partai petahana atau lahir menjadi gurita politik untuk membangun kekuatan baru.

Birokrasi Kabupaten Belu sebagai bagian dari birokrasi Indonesia memiliki gejala yang sama. ASN sering berada pada ruang dilemma untuk berpijak; antara 'mengamankan diri' dengan cara berpihak pada keinginan politik eksekutif dan berpijak pada sumpah profesi sebagai pribadi netral untuk berorintasi pada pelayanan masyarakat.

Fungsi ganda biroktrasi sebagai alat/aparatur negara dan pelayan masyarakat mengharuskan bersikap netral/tidak memihak sebagaimana digariskan dalam undang-undang. Hal ini memang rumit. Bagaimana mungkin seorang birokrat sebagai alat pemerintah dalam hal ini kepala eksekutif tidak berpihak kepada 
pemerintah dalam hal ini bupati? Apalagi bupati juga ikut bertarung dalam pemilihan kepala daerah. sudah barang tentu birokrat akan cenderung berpihak dan ikut mendukung petahana. Hal ini lumrah terjadi karena birokrat merupakan anak buah kepala eksekutif.

Sikap tidak netral ditujukan dengan cara menggunakan jabatan untuk menekan bawahan, menggunakan alat layanan untuk mempengaruhi masyarakat, terlibat dalam kampanye dan melakukan sosialaisasi. Komisi ASN Kabupaten Belu akhirnya menjatuhkan sanksi kepada sembilan camat yang tidak bersikap netral dalam ajang pemilihan bupati dan wakil bupati Kabupaten Belu periode 20202025. ASN dimaksud adalah camat Kecamatan Lamaknen (Hiro Mau Luma), camat Kecamatan Lamaknen Selatan (Wande Mesak Mali) camat Kecamatan Raihat (Ather Reinmalae), camat Kecamatan Kota Atambua (Vinsen Mau), camat Kecamatan Atambua Barat (Petrus Manek), camat Kecamatan Atambua Selatan (Silvia Amaral), camat Kecamatan Tasifeto Barat (Vinsen Bere), camat Kecamatan Raimanuk (Tarsi Edi), camat Kecamatan Nanaet Duabesi (Mikhael Bria) dan satu orang perangkat organisasi perangkat daerah (OPD) Kabupaten Belu (www.nttonlinenow.com 2020/11/05)

Ketidaknetralan sembilan orang camat dalam pemilihan kepala daerah kepala daerah serentak tanggal 9 Desember 2020 disebabkan oleh (1) birokrat dibawah kendali eksekutif. Camat berada di bawah kendali bupati karena ditunjuk dan dilantik oleh bupati. Bupati sebagai pejabat politik yang dan camat sebagai birokrat. Di sini dua hal yang sedikit berbeda disatukan dalam sebuah wadah. Nalar politik tidak persis sama dengan nalar birokrat. Politik kadang memikirkan bagaimana memenangkan kursi eksekutif, mendapat apa, pada saat kapan. Dalam bahasa Harold D. Lasswell, siapa memperoleh apa, kapan dan bagaimana (who gets what, when and how) Ramlan Surbakti; 2017 hal. 1, sementara birokrat yang berkedudukan sebagai pelayan masyarakat memikirkan bagaimana layanan pemerintah memuaskan masyarakat sebagai penerima layanan, pemegang kedaulatan tertinggi dalam demokrasi.

Sebetulnya kedua perbedaan tersebut bisa didamaikan dan dijadikan satu kekuatan untuk membangun bangsa dan masyarakat. Dalam praktek malah berjalan terbalik. Birokrat ditempatkan berdasarkan kepentingan satu 'kelompok'. Hal ini mengakibatkan terjadinya kampanye terselubung oleh pihak birokrat kepada pasangan calon tertentu sebagai bagian dari balas jasa.

Hal ini berdampak lanjut pada pemberian layanan oleh birokrat. Birokrat seakan dikekang untuk memberikan layanan di bawah kendali pemberi jabatan. Birokrat menghadirkan dan memberikan layanan yang istimewa kepada masyarakat yang mendukung pasangan calon untuk menarik simpati masyaratk pemilih sebagai bentuk balas jasa.

(2) Birokrat sebagai subyek yang memiliki kecenderungan. Sebagai subyek birokrat tentu memiliki kecenderungan untuk mendukung dan menjatuhkan pilihan pada paslon tertentu. Hal ini menyebabkan birokrat cenderung berpihak. Tindakan keberpihakan birokrat kepada pasangan calon dengan sendirinya menyalahi kodratnya sebagai pelayan dan abdi yang tidak boleh memihak pasangan calon tertentu.

Fenomena ini sering tidak nampak secara kasat mata. Istilah yang sering digunakan adalah 'bermain halus', 'bermain cantik', 'abu-abu' dan lain sebagainya. Kecenderungan tersebut membuat birokrat memudahkan layanan kepada masyarakat yang dianggap sebagai satu komplotan dan menerapkan aturan secara ketat bagi masyarakat yang dianggap berlainan pilihan.

Birokrat cenderung menjadikan pelayanan yang merupakan tugas pokoknya sebagai alat kampanye terselubung untuk mempromosikan pasangan calon yang menjadi pilihannya.

Fenomena ini juga ditemukan di Kabupaten Belu dalam pemilihan kepala daerah 
serentak tanggal 9 Desember Tahun 2020. Dinamika politik memunculkan kelompok SAHABAT dan kelompok SEHATI, orang SAHABAT dan orang SEHATI. Reaksi timbulnya kelompok secara alamiah akibat gesekan politik turut mempengaruhi pemberian pelayanan. Masyarakat dan birokrat merasa berada pada dua kotak yakni kotak SAHABAT dan kotak SEHATI. Hal ini jelas mempengaruhi semangat memberikan pelayanan oleh para birokrat, dan semangat masyarakat untuk meminta layanan kepada birokrat. Persoalan ini kada berlanjut selama bertahun-tahun.

(3) birokrasi cenderung tampil sebagai gurita politik. Tampilnya birokrasi sebagai kekuatan politik karena menyadari jumlah masa, pengaruh, power yang dibungkus melalui pelayanan menyebabkan birokrasi kadang cenderung membentuk kekuatan politik baru.

\section{KESIMPULAN}

Netralitas ASN/birokrat merupakan polemic tak berujung. Persoalan ini makin besar dalam lingkup politik lokal di tingkat Kabupaten karena kecil ruang politiknya. Makin kecil ruang politik maka gesekan makin terasa. ASN yang memiliki kepentingan jabatan sudah tentu condong pada pasangan calon yang dianggap lebi berpeluang untuk menang atau menjanjikan jabatan. Kondisi ini membuat ASN/birokrat sulit bersikap netral berdasarkan ketentuan yang berlaku. Masih adanya kecenderungan untuk bermain dengan mengembangkan taktik 'bermain cantik'.

\section{SARAN}

Penulis menyarankan kepada seluruh elemen agar

1. Seluruh komponen termasuk masyarakat umum untuk turut berpartisipasi mengawas terlaksananya politik lokal yang bermartabat

2. Perlunya sanksi yang tegas bagi para ASN yang melanggar aturan sehingga menimbulkan efek jera.
3. Perlunya lelang jabatan melalui test terbuka bagi seluruh OPD, termasuk jabatan camat sehingga dapat meminimalisir adanya politik balas jasa antara eksekutif dengan birokrat/ASN

\section{DAFTAR PUSTAKA}

\section{Buku/Literatur}

Dwiyanto, Agus (2008). Reformasi Birokrasi Public Di Indonesia (p.32). Yogyakarta: Gajah Mada University Press

Lipsky, Mikhael. (1980). Street-Level Bureaucracy: Dilemans of The Individual In Public Service. New York: Rusel Sage Foundation

Osborne, David \& Peter, Plastrik. (1997). Banishing Bureaucracy: The Five Strategies For Reinventing Goverment. California: Addison-Weshley Publishing Company, inc

Osborne David \& Ted Gabler. 1992. Mewirausahakan Birokrasi: Mentrasformasikan Semangat Wirausaha Kedalam Sector Public. Jakarta: Pustaka Binaman Pressindo

Siagian, Sondang, 1984. Patolohgi Birokrasi Analisis, Identifikasi Dan Terapinya. Jakarta: Ghalia Indonesia

Surbakti, Ramlan. (2007). Memahami Ilmu Politik (p. 1, 183). Jakarta:Grasindo

\section{Sumber On Line}

infopemilu2.kpu.go.id

belukab.go.id

timexkupang.com 15/02/21

www.nttonlinenow.com 2020/11/05 